\title{
PENGARUH BUSUR SUDU TURBIN ANGIN SAVONIUS TIPE-U MENGGUNAKAN PERANGKAT LUNAK
}

\author{
Delffika Canra \\ Jurusan Teknik Mesin \\ Politeknik Negeri Indramayu \\ Email: delffika.canra@polindra.ac.id \\ Suliono \\ Jurusan Teknik Mesin \\ Politeknik Negeri Indramayu \\ Email: Suliono@polindra.ac.id
}

\begin{abstract}
ABSTRAK
Seringnya pemadaman listrik oleh PLN di beberapa daerah di Indonesia tak terkecuali di Indramayu, serta naiknya tarif listrik sejak awal tahun 2017 membawa dampak negatif pada rakyat indonesia yang sangat konsumtif dan tergantung pada energi listrik. Sumber energi angin didaerah pesisir Indonesia umumnya merupakan salah satu potensi sumber energi terbarukan (renewable energy resources) yang berlimpah, ramah lingkungan dan bersifat renewable. Turbin angin savonius dapat menghasilkan torsi yang relatif tinggi meskipun pada kecepatan angin rendah. Untuk mendapatkan daya listrik yang besar diperlukan konstruksi turbin yang besar juga dimana memerlukan biaya yang besar juga tentunya. Untuk itu perlu dikembagkan dimensi dari konstruksi turbin angin ini. Aspek yang sudah diteliti adalah penampang sudu, serta nilai lainnya. Sedangkan kedalaman lengkungan atau panjang busur sudu pada tipe U masih berpeluang diteliti. Oleh karena itu perlu dilakukan penelitian pada busur sudu tipe U untuk mendapatkan daya yang lebih besar dari sebelumnya. Metode numerikal dilakukan untuk mengetahui berapa besar pengaruh modifikasi geometri sudu terhadap daya turbin yang terserap. Turbin didesain dengan jumlah sudu 2 buah sesuai dengan penelititan sebelumnya. Parameter yang divariasikan hanya pada geometri panjang busur dan lebar penampang sudu, parameter lainnya mengikuti penelitian sebelumnya. Dari hasil simulasi radius dan lebar penampang membuktikan ada pengaruh geometri dalam peningkatan daya turbin berturut-turut sebesar 7,78 \% dan 19,76\%. Variasi sudu yang menghasilkan daya terbesar terdapat pada variasi sudu R 75 dan LP 130 pada kecepatan angin $4,8 \mathrm{~m} / \mathrm{s}$.
\end{abstract}

Kata kunci: turbin angin savonius tipe-u; panjang busur; lebar penampang; daya angin.

\begin{abstract}
The frequent outages of electricity by PLN in several regions in Indonesia are no exception in Indramayu, and rising electricity tariffs since the beginning of 2017 have a negative impact on Indonesian people who are very consumptive and dependent on electricity. Wind energy sources in coastal areas of Indonesia are generally one of the potential renewable energy sources (renewable energy resources) that are abundant, environmentally friendly and renewable. Savonius wind turbines can produce relatively high torque even at low wind speeds. To get a large amount of electrical power, a large turbine construction is also needed which also requires a large amount of money, of course. For this reason the dimensions of this wind turbine construction need to be developed. The aspects that have been investigated are blade cross sections, as well as other values. Whereas the arch depth or blade length of type $U$ is still likely to be studied. Therefore it is necessary to do research on type U blade arcs to get more power than before. The numerical method is carried out to determine how much influence the modification of blade geometry has on the absorbed turbine power. The turbine is designed with a number of 2 pieces of blades according to previous research. Parameters varied only on the geometry of the arc length and the width of the blade, other parameters following the previous study. From the results of simulation of radius and cross section width prove there is a geometrical effect in increasing turbine power in a row of $7.78 \%$ and $19.76 \%$. The variation of blades that produce the greatest power is in the variations of $R 75$ and LP 130 blades at wind speeds of $4.8 \mathrm{~m} / \mathrm{s}$.
\end{abstract}

Keywords: u-type savonius wind turbine; bow length; cross section; wind power. 


\section{PENDAHULUAN}

Seringnya pemadaman listrik oleh PLN di beberapa daerah di Indonesia tak terkecuali di Indramayu, serta naiknya tarif listrik sejak awal tahun 2017 membawa dampak negatif pada rakyat indonesia yang sangat konsumtif dan tergantung pada energi listrik. Hal ini menginspirasi untuk mencari sumber energi alternatif yang dapat menghasilkan energi listrik, salah satunya adalah energi angin.

Sumber energi angin didaerah pesisir Indonesia umumnya merupakan salah satu potensi sumber energi terbarukan (renewable energy resources) yang berlimpah, ramah lingkungan dan bersifat renewable. Kecepatan angin di Indonesia secara umum rata-rata 3 - $7 \mathrm{~m} / \mathrm{s}$ yang tergolong kecepatan angin rendah[3]. Untuk memanfaatakan potensi angin ini, turbin yang terbaik digunakan adalah turbin angin savonius karena dapat berputar pada kecepatan angin rendah[1][3]. Kelebihan turbin angin savonius dapat menghasilkan torsi yang relatif tinggi meskipun pada kecepatan angin rendah. Karena itu sangat baik sekali dikembangkan untuk menghasilkan energi listrik. Banyak sekali penelitian yang sudah dilakukan untuk mengembangkan konstruksi turbin angin ini dan terus dikembangkan untuk menghasilkan daya listrik yang optimal. Pengembangan konstruksi yang sudah dilakukan adalah memvariasikan bentuk sudu, jumlah sudu, sudut sudu, tingkat sudu (multi stage), penahan (shield) dan pengarah (deflector), sehingga banyak sekali jenis sudu yang ada pada turbin ini mulai dari tipe U (bucket) yang merupakan tipe sudu awal ditemukan atau konvensional, tipe L, sudu miring (twisted-blade), sudu bertingkat dan lainnya.

Untuk mendapatkan daya listrik yang besar diperlukan konstruksi turbin yang besar juga dimana memerlukan biaya yang besar juga tentunya. Untuk itu perlu dikembagkan geometri dari konstruksi turbin angin ini. Aspek yang sudah diteliti adalah penampang sudu, serta nilai parameter lainnya. Sedangkan kedalaman lengkungan atau panjang busur sudu pada tipe $U$ masih berpeluang diteliti. Oleh karena itu perlu dilakukan penelitian pada busur sudu tipe U untuk mendapatkan daya yang lebih besar dari sebelumnya. Dengan memvariasikan geometri busur sudu, diharapkan akan meningkatkan daya angin yang terserap oleh turbin. Daya angin yang dapat diserap oleh rotor turbin angin sangat mempengaruhi daya listrik yang dihasilkan oleh generator nantinya.

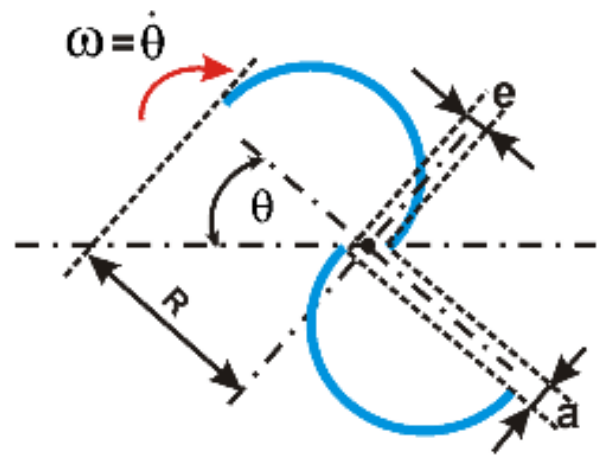

\section{Gambar 1. Skema Nilai Parameter Geomatrikal Sudu Turbin Savonius [5]}

Penelitan yang dilakukan oleh Mohamed Hasan A. M dalam desertasinya pada tahun 2011 dengan judul "Design Optimazation of Savonius and Wells Turbines", mengungkapkan bahwa ada beberapa metoda untuk meningkatkan performa dari turbin angin savonius tipe U (conventional savonius rotors). Pertama adalah menempatkan deflecting plate didepan sudu turbin. Hal ini meningkatkan Cp (Coefficient of Power) sebesar $20 \%$. Metoda kedua yakni multi steps atau sudu bertingkat. Sudu ini dapat bergerak awal dengan baik (good self-starting) akan tetapi mengalami penurunan $\mathrm{Cp}$ sebesar $30 \%$. Ketiga yakni Guide vanes dimana Cp yang dihasilkan 3 sudu lebih kecil dibandingkan 2 sudu. Metoda ini meningkatkan torsi pada TSR (Tip Ratio Speed) 0 hingga 0,3 akan tetapi menurunkan torsi apabila TSR melebihi dari 0,3. Oleh karena itu sudu ini tergantung sekali dengan kecepatan angin. Metoda yang keempat adalah twisted-blade (sudu miring), Cp yang dihasilkan meningkat 27\%, sedangkan kelemahan dari sudu ini adalah butuh biaya mahal dalam pembuatan sudu. Kelima, sudu turbin menggunakan guide-box tunnel sebagai penahan (deflector) angin untuk mencegah sudu berbalik (returning blade). $\mathrm{Cp}$ meningkat 50\% pada 3 sudu, kelemahannya hanya pada konstruksi yang kompleks. Yang keenam adalah memodifikasi sudu dengan cara memberikan nilai parameter geometrikal yakni nilai overlap dan sudut antara sudu (lihat Gbr.1). Hal ini meningkatkan $\mathrm{Cp}$ sebesar $60 \%$, dan menghasilkan vibrasi yang besar. Metode yang keenam selalu digunakan dalam mendesain sudu turbin karena sudah terbukti meningkatkan $\mathrm{Cp}$ lebih signifikan dari desain sudu konvensional. 


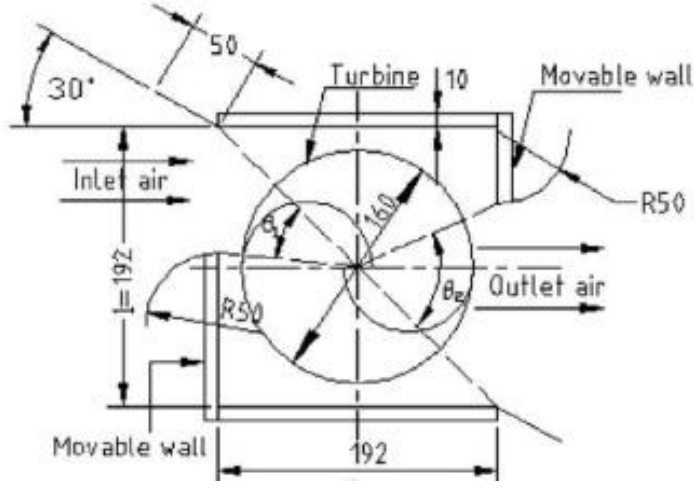

(a)

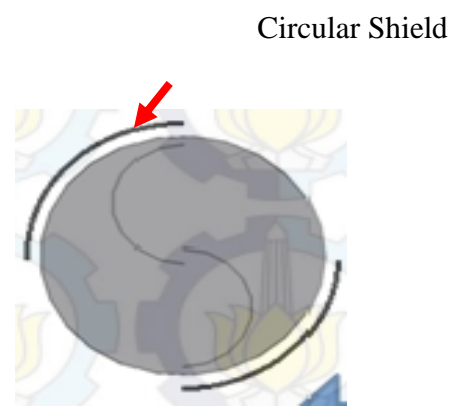

(b)

Gambar 2. Skema Turbin Angin Menggunakan (a) Guide-Box Tunnel [5] (b) Circular Shield [2]

M. Haydarul H. dkk pada tahun 2013 dengan judul penelitian "Rancang Bangun Turbin Angin Vertikal Jenis Savonius dengan Variasi Jumlah Blade Terintegrasi Circular Shield untuk Memperoleh Daya Maksimum", mendapatkan nilai Cp yang signifikan yakni rata-rata $80 \%$ dibandingkan dengan sudu savonius tipe U konvensional. Peneliti ini menggunakan metode yang kelima yakni menggunakan guidebox tunnel (kotak laluan angin), hanya saja dimodifikasi berbentuk silinder (Circular Shield). Nilai parameter geometrikal yang dipakai adalah nilai overlap sebesar $20 \%$ dari diameter endplate. Kemudian aspek rasio sudu adalah $1: 4$. Pada penelitian ini juga membuktikan bahwa peforma sudu yang terbaik adalah Pada Saat Jumlah Sudu Sebanyak 2 Dibandingkan Dengan Jumlah Sudu Yang Lebih Dari 2. Hal Ini Diasumsikan Oleh Peneliti Dikarenakan Beban Material Mempengaruhi Putaran Sudu.

Metode Numerical Dilakukan Untuk Mengetahui Berapa Besar Pengaruh Modifikasi Geometri Sudu Terhadap Daya turbin yang terserap. Simulasi aliran udara menggunakan perangkat lunak solid work bisa memperlihatkan perbedaan kecepatan angin sebelum dan sesudah melewati turbin. Perbedaan kecepatan angin sangat mempengaruhi daya angin dan daya turbin. Selama ini penelitian tentang geometri busur sudu belum dilakukan. Aspek yang sudah ditetiliti yakni penampang sudu yang akan dilewati angin, dengan ratio 1:4 dan aspek lainya seperti banyaknya jumlah sudu, dan lainnya. Manfaat dari penelitian ini adalah selain untuk meningkatkan daya listrik juga untuk mengurangi material pembuatan turbin, dan tentu saja bisa mengurangi biaya produksi. Selain itu dapat menjadi sarana informasi dalam merancang turbin angin savonius tipe-U.

\section{METODOLOGI PENELITIAN}

Penelitian ini menggunakan metode numerical atau simulasi berbasis perangkat lunak solid work, yakni simulasi aliran angin pada sudu. Tahap awal adalah mendesain turbin dengan variasi geometri sudu. Variasi pertama adalah memvariasikan radius(R) sudu mulai dari R60-R80 dengan resolusi $5 \mathrm{~mm}$, sedangkan lebar penampang sudu konstan yakni $100 \mathrm{~mm}$. Variasi kedua adalah memvariasikan lebar penampang(LP) sudu mulai dari LP80-LP130 dengan resolusi $10 \mathrm{~mm}$, sedangkan panjang busur konstan yakni $157 \mathrm{~mm}$ (lihat gambar 4). Sedangkan desain sudu normal atau original sesuai dengan penelitian sebelumnya yakni lebar penampang $100 \mathrm{~mm}$ dan radius $50 \mathrm{~mm}$ seperti diperlihatkan pada gambar 3 dibawah ini. Nilai parameter lainnya konstan.

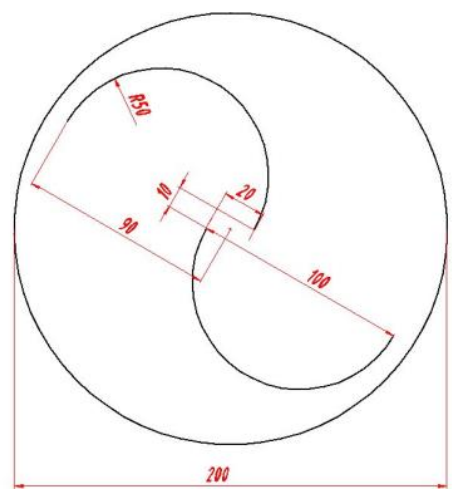

Gambar 3. Geometri Desain Sudu Original 
Sudu turbin dibuat bervariasi sebagai sampel simulasi pada perangkat lunak seperti yang dapat dilihat pada gambar 4. Variasi yang dibuat adalah variasi Radius mulai dari radius $60 \mathrm{~mm}$ hingga $80 \mathrm{~mm}$ dengan resolusi $5 \mathrm{~mm}$, dan setiap sampel diberi label dengan huruf besar R (radius) diikuti dengan besar radius, contoh R60 yang artinya radius sudu $60 \mathrm{~mm}$. Kemudian dibuat juga variasi Lebar penampang dengan label LP mulai dari ukuran $80 \mathrm{~mm}$ hingga $130 \mathrm{~mm}$ dengan resolusi $10 \mathrm{~mm}$. Pada gambar 4 juga dapat dilihat banyaknya variasi bentuk lengkungan sudu yang diharapkan akan mempengaruhi daya angin pada turbin angin savonius tipe-u ini.

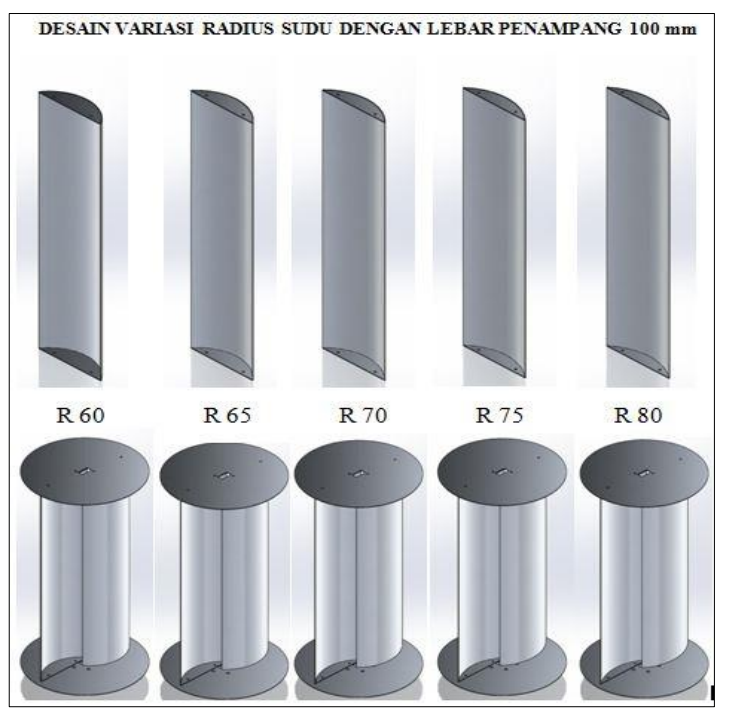

(a)

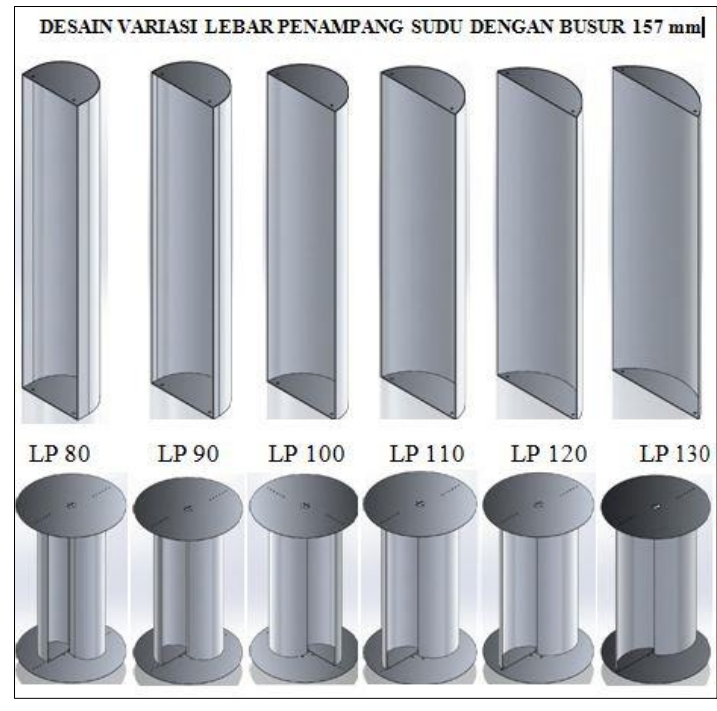

(b)

Gambar 4. Desain Geometri Variasi Sudu (a) Radius (b) Lebar Penampang

Kecepatan udara pada simulasi ini divariasikan mulai dari 3,6 - 4,8 m/s dan menggunakan circular shield [2] seperti yang dilakukan pada penelitian sebelumnya. Adapun tahap simulasi adalah setelah membuat desain varasi sudu, kemudian dibuatkan box tunnel untuk batas aliran udara yang akan dikenakan pada varaian sudu. Data yang diambil dari simulasi ini adalah data perbedaan kecepatan udara (angin) yang masuk dan keluar dari turbin. Data yang didapatkan akan diolah dan dihitung secara teoritis untuk mendapatkan daya turbin.

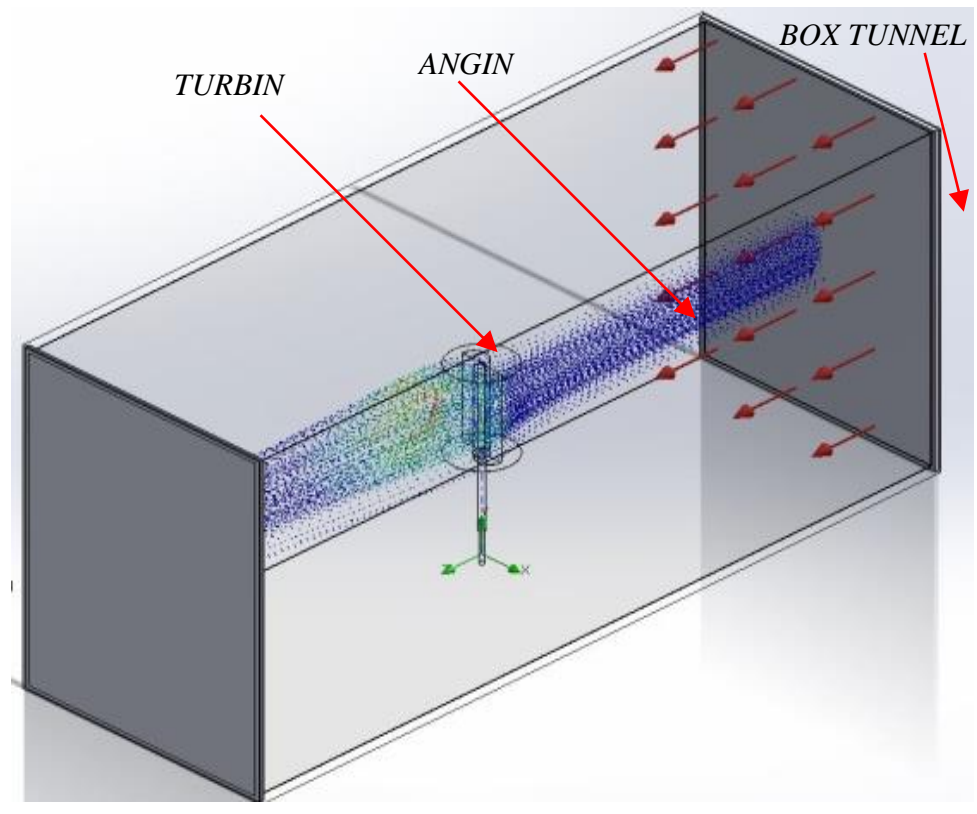

\section{Gambar 5. Skema Simulasi pada Perangkat Lunak Solidwork}

Dengan menggunakan teori momentum Betz [5] dimana angin kecepatan $\mathrm{v}_{1}$ melewati sebuah sudu turbin angin mengalami perubahan kecepatan $\mathrm{v}_{2}$, sehingga daya turbin yang bekerja dapat diformulasikan : 
$P=\frac{1}{4} \rho A\left(v_{1}+v_{2}\right) \cdot\left(v_{1}^{2}-v_{2}^{2}\right)$

Koefisien daya atau Coefficient of power $(\mathrm{Cp})$ menentukan performa dari turbin angin tersebut dimana energi angin menentukan besarnya energi kinetik angin yang melalui sudu turbin angin tersebut dan dapat diformulasikan :

$P_{0}=\frac{1}{2} \rho A v_{1}^{3}$

Sehingga Koefisien daya turbin dapat diformulasikan :

$$
C p=\frac{P}{P_{0}}=\frac{\frac{1}{4} \rho A\left(v_{1}+v_{2}\right) \cdot\left(v_{1}^{2}-v_{2}^{2}\right)}{\frac{1}{2} \rho A v_{1}^{3}}
$$

\section{Daftar Notasi}

$$
\begin{aligned}
& \mathrm{P}: \text { Daya turbin (watt) } \\
& \rho \text { : Kerapatan udara }\left(1,29 \mathrm{~kg} / \mathrm{m}^{3}\right) \\
& \mathrm{A}: \text { Luas area sapuan }\left(\mathrm{m}^{2}\right) \\
& \mathrm{v}: \text { Kecepatan angin }(\mathrm{m} / \mathrm{s}) \\
& \mathrm{P}_{0}: \text { Daya angin }(\mathrm{watt}) \\
& \mathrm{Cp}: \text { Koefisien power }
\end{aligned}
$$

\section{HASIL DAN PEMBAHASAN}

\subsection{Simulasi Variasi Radius}

Dengan memvariasikan radius sudu turbin, dapat dilihat dari hasil simulasi bahwa ada perbedaan kecepatan angin masuk dengan kecepatan angin keluar. Perbedaan kecepatan angin akan mempengaruhi daya angin dan daya turbin (Gambar 6). Angin yang mengalir masuk kedalam turbin dan ditangkap oleh sudu mengurangi kecepatan angin sehingga sudu akan terseret, kemudian angin akan keluar dari turbin dibagian belakang yang sudah mengalami penurunan kecepatan. Dari gambar 6 dapat dilihat bulir-bulir berwarna menunjukkan angin yang mengalir mengalami perubahan warna pada saat menumbuk sudu (penurunan kecepatan). Data yang diambil dari simulasi ini adalah kecepatan angin saat angin akan menumbuk sudu dan sesaat setelah melewati sudu.

Kecepatan angin yang sudah di-setting mengalami penurunan kecepataan saat hampir menumbuk sudu, fenomena ini diperlihatkan adanya perubahan warna bulir-bulir angin pada gambar 6 . Kemungkinan adanya turbulensi pada saat angin akan menumbuk sudu. Kemudian kecepatan angin terus akan menigkat kembali saat menjauh dari sudu (diperlihatkan pada gambar 6 yakni perbedaan warna bulir-bulir).

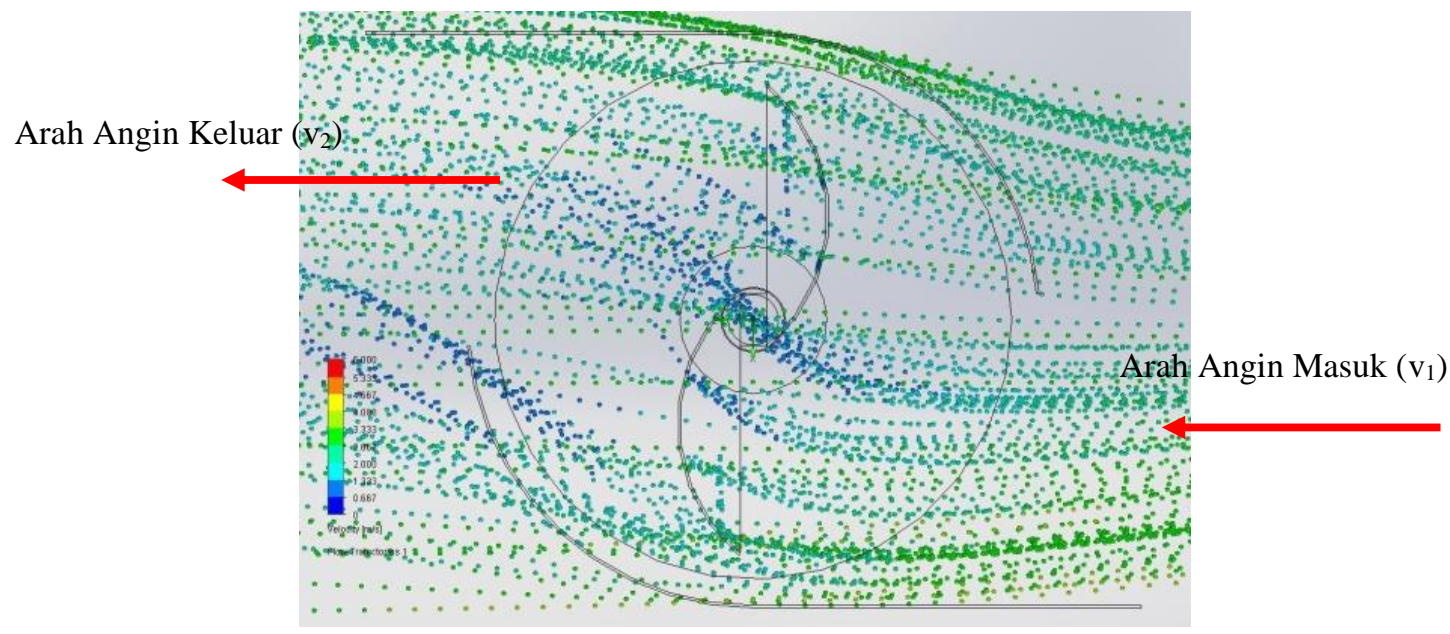

Gambar 6. Contoh Hasil Simulasi Kecepatan Angin Variasi Radius 
Dengan desain sudu menggunakan ukuran overlap pada titik tengah sudu akan mengurangi pengaruh dari turbulensi yang terjadi pada sudu, sehingga kecepatan angin tidak akan mengalami penurunan kecepatan secara signifikan. Akan tetapi turbulensi terbesar terjadi pada titik tengah dari sudu tersebut, hal ini diperlihatkan pada gambar 6, adanya kecepatan angin yang menurun dan bertumpuk pada titik tengah sudu.

Dari hasil pengolahan data (tabel 1), radius R70 dan R75 menghasilkan daya turbin yang terbesar pada kecepatan angin 4,8 m/s. Akan tetapi koefisien power (Cp) tidak menunjukkan perbedaan yang terlalu signifikan dengan variasi suda lainnya. Kecepatan angin dibawah 4,8 m/s masih menunjukkan perbedaan kecepatan angin masuk dan keluar dari sudu belum berselisih signifikan, sehingga dari pengolahan data tidak menunjukkan daya angin yang besar.

Tabel 1. Hasil Pengolahan Data Simulasi Variasi Radius

\begin{tabular}{|c|c|c|c|c|c|c|}
\hline No & Radius & $v_{1}[\mathrm{~m} / \mathrm{s}]$ & $v_{2}[\mathrm{~m} / \mathrm{s}]$ & $P$ [watt] & $P_{0}[w a t t]$ & $C p$ \\
\hline \multirow{4}{*}{1} & \multirow{4}{*}{ R60 } & 3,6 & 2 & 0,647 & 1,204 & 0,54 \\
\hline & & 4 & 2,6 & 0,787 & 1,651 & 0,48 \\
\hline & & 4,4 & 3 & 0,989 & 2,198 & 0,45 \\
\hline & & 4,8 & 3,3 & 1,270 & 2,853 & 0,44 \\
\hline \multirow{4}{*}{2} & \multirow{4}{*}{ R65 } & 3,6 & 2,6 & 0,496 & 1,204 & 0,41 \\
\hline & & 4 & 2,6 & 0,787 & 1,651 & 0,48 \\
\hline & & 4,4 & 3,3 & 0,841 & 2,198 & 0,38 \\
\hline & & 4,8 & 3,3 & 1,270 & 2,853 & 0,44 \\
\hline \multirow{4}{*}{3} & \multirow{4}{*}{ R70 } & 3,6 & 2 & 0,647 & 1,204 & 0,54 \\
\hline & & 4 & 2 & 0,929 & 1,651 & 0,56 \\
\hline & & 4,4 & 2,3 & 1,216 & 2,198 & 0,55 \\
\hline & & 4,8 & 2,3 & 1,626 & 2,853 & 0,57 \\
\hline \multirow{4}{*}{4} & \multirow{4}{*}{ R75 } & 3,6 & 2,3 & 0,584 & 1,204 & 0,48 \\
\hline & & 4 & 2,3 & 0,870 & 1,651 & 0,53 \\
\hline & & 4,4 & 2,6 & 1,138 & 2,198 & 0,52 \\
\hline & & 4,8 & 2,6 & 1,554 & 2,853 & 0,54 \\
\hline \multirow{4}{*}{5} & \multirow{4}{*}{$\mathrm{R} 80$} & 3,6 & 2,6 & 0,496 & 1,204 & 0,41 \\
\hline & & 4 & 2,6 & 0,787 & 1,651 & 0,48 \\
\hline & & 4,4 & 3 & 0,989 & 2,198 & 0,45 \\
\hline & & 4,8 & 3 & 1,413 & 2,853 & 0,50 \\
\hline
\end{tabular}

Simulasi variasi sudu ini telah membuktikan bahwa geometri sudu mempengaruhi peningkatan daya turbin, sehingga akan mempengaruhi daya listrik yang akan didapatkan dari generator.

\subsection{Simulasi Variasi Lebar Penampang}

Simulasi variasi lebar penampang merupakan variasi lainnya untuk melihat pengaruh busur sudu terhadap daya angin yang bisa diserap. Dari hasil simulasi menunjukkan ada perbedaan kecepatan angin antara yang masuk dengan keluar dari sudu.(Gambar 7).

Pada variasi lebar penampang ini, luas penampang dari sudu mengalami perubahan dari versi original, sehingga akan mempengaruhi daya dorongan angin. Pada variasi dibawah LP100 (original) mengalami penyusutan luas penampang untuk menangkap energi angin, sedangkan diatas LP100 mengalami perluasan penampang untuk penangkapan energi angin. Seperti gambar 7 menunjukkan LP80 mengalami pemendekan lebar panmpak yang berdampak luas penampang menurun. 


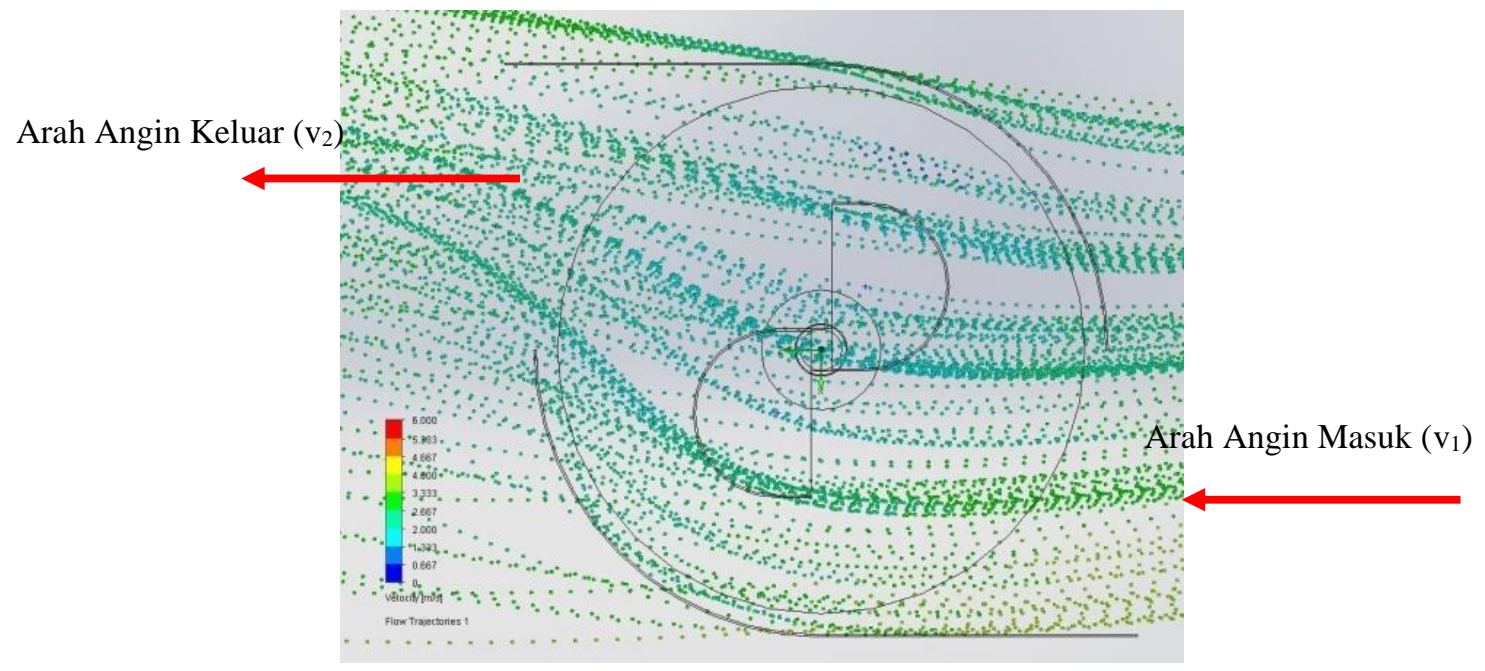

Gambar 7. Contoh Hasil Simulasi Kecepatan Angin Variasi Lebar Penampang

Dari hasil pengolahan data (tabel 2), Lebar penampang LP120 dan 130 menghasilkan daya turbin yang terbesar pada kecepatan angin 4,8 m/s. Akan tetapi koefisien power (Cp) menunjukkan perbedaan yang tidak terlalu signifikan dengan variasi suda lainnya. Hampir sama dengan variasi radius, perbedaan kecepatan angin masuk dan keluar tidak begitu signifikan pada kecepatan angin dibawah 4,8 m/s.

Fenomena ini membuktikan daya angin yang diserap turbin akan baik atau akan mengalami peningkatan mulai dari kecepatan angin $4,8 \mathrm{~m} / \mathrm{s}$ dan seterusnya. Untuk itu perlu dilakukan penelitian lanjutan untuk meningkatkan kecepatan angin diatas $4,8 \mathrm{~m} / \mathrm{s}$.

Tabel 2. Hasil Pengolahan Data Simulasi Variasi Lebar Penampang

\begin{tabular}{|c|c|c|c|c|c|c|}
\hline No & $\begin{array}{c}\text { Lebar } \\
\text { Penampang }\end{array}$ & $v_{1}[\mathrm{~m} / \mathrm{s}]$ & $v_{2}[\mathrm{~m} / \mathrm{s}]$ & $P$ [watt] & $P_{0}[w a t t]$ & $C p$ \\
\hline \multirow{4}{*}{1} & \multirow{4}{*}{ LP80 } & 3,6 & 2,6 & 0,397 & 0,963 & 0,41 \\
\hline & & 4 & 2,6 & 0,629 & 1,321 & 0,48 \\
\hline & & 4,4 & 2,6 & 0,910 & 1,758 & 0,52 \\
\hline & & 4,8 & 3,3 & 1,016 & 2,283 & 0,44 \\
\hline \multirow{4}{*}{2} & \multirow{4}{*}{ LP90 } & 3,6 & 2,6 & 0,446 & 1,083 & 0,41 \\
\hline & & 4 & 2,6 & 0,708 & 1,486 & 0,48 \\
\hline & & 4,4 & 3 & 0,890 & 1,978 & 0,45 \\
\hline & & 4,8 & 3,3 & 1,143 & 2,568 & 0,44 \\
\hline \multirow{4}{*}{3} & \multirow{4}{*}{ LP100 } & 3,6 & 2 & 0,647 & 1,204 & 0,54 \\
\hline & & 4 & 1,3 & 0,978 & 1,651 & 0,59 \\
\hline & & 4,4 & 2 & 1,268 & 2,198 & 0,58 \\
\hline & & 4,8 & 2 & 1,670 & 2,853 & 0,59 \\
\hline \multirow{4}{*}{4} & \multirow{4}{*}{ LP110 } & 3,6 & 1,6 & 0,767 & 1,324 & 0,58 \\
\hline & & 4 & 1,6 & 1,068 & 1,816 & 0,59 \\
\hline & & 4,4 & 2 & 1,395 & 2,418 & 0,58 \\
\hline & & 4,8 & 2 & 1,837 & 3,139 & 0,59 \\
\hline \multirow{4}{*}{5} & \multirow{4}{*}{ LP120 } & 3,6 & 1,3 & 0,855 & 1,444 & 0,59 \\
\hline & & 4 & 1,3 & 1,174 & 1,981 & 0,59 \\
\hline & & 4,4 & 1,6 & 1,560 & 2,637 & 0,59 \\
\hline & & 4,8 & 2 & 2,004 & 3,424 & 0,59 \\
\hline \multirow{4}{*}{6} & \multirow{4}{*}{ LP130 } & 3,6 & 1,3 & 0,926 & 1,565 & 0,59 \\
\hline & & 4 & 1,6 & 1,262 & 2,147 & 0,59 \\
\hline & & 4,4 & 2 & 1,649 & 2,857 & 0,58 \\
\hline & & 4,8 & 2,6 & 2,020 & 3,709 & 0,54 \\
\hline
\end{tabular}

Dari simulasi ini telah membuktikan bahwa geometri sudu mempengaruhi peningkatan daya turbin, juga daya listrik yang kan dihasilkan generator. 


\section{KESIMPULAN}

Dari hasil simulasi radius dan lebar penampang membuktikan ada pengaruh geometri dalam peningkatan daya turbin berturut-turut sebesar $7,78 \%$ dan $19,76 \%$. Variasi sudu yang menghasilkan daya terbesar terdapat pada variasi sudu R 75 dan LP 130 pada kecepatan angin 4,8 m/s.

\section{DAFTAR PUSTAKA}

[1] Sumiati. R. Pengujian Turbin Angin Savonius Tipe U sudu di Lokasi Pantai Air Tawar Padang. Jurnal Teknik Mesin Politeknik Negeri Padang, Juni 2012; 1(1): 26-32.

[2] M. Haydarul. H, Nugroho. G, Musyafa'.A. Rancang Bangun Turbin Angin Vertikal Jenis Savonius dengan Variasi Jumlah Blade Terintegrasi Circular Shield untuk Memperoleh daya Maksimum. Jurnal Teknik POMITS. 2013; 7(7): 1-6.

[3] Rudianto D.T, Ahmadi N. Rancang Bangun Turbin Angin Savonius 200 Watt. Seminar Nasional Teknologi Informasi dan Kedirgantaraan (SENATIK). Yogyakarta. 2016; 2: 71-75.

[4] Farid. A. Optimasi Daya Turbin Angin Savonius dengan Variasi Celah dan Perubahan Jumlah Sudu. Prosiding SNST ke-5 Fakultas Teknik Universitas Wahid Hasyim. Semarang. 2014; 5: 18-23.

[5] Mohamed Hasan A.M. Design Optimazation of Savonius and Wells Turbines. Disertasi. University of Magdeburg, Magdeburg; 2011. 